\title{
INVESTIGATION OF LOSSES IN INSULATION OF HIGH-VOLTAGE CABLES WITH XLPE INSULATION
}

In this paper the authors calculate the losses in insulation system cable with XLPE-polyethylene as a solid dielectric insulation and with semiconductor polyethylene used as a conductor screen and a insulation screen. The paper is devoted to the investigation of losses in the insulation system of high-voltage XLPE-cables. The line of XLPE-cables in group running horizontally, provided that the cables are of equal diameter and emit equal losses. It is limited to the following: the air flow around the cables may be necessary restricted by proximity to next cables. The dielectric losses are voltage depended and related to the insulation system materials being used. All current in this insulation system are complex quantities containing both real (Re(I)) and imaginary (Im(I)) parts. Values of the loss factor of the insulation system at power frequency tg $\delta$ are given astg $\delta=\operatorname{Re}(I) / I m(I)$. It was proposed the quantities criterion of the loss factor of the insulation system to high voltage XLPE-cables. The work is devoted to creation of a method for calculation of the current rating of high-voltage cables in conditions function. References 7, figures 2.

Key words: power cable, XLPE-cable, insulation losses, insulation system, loss factor.

Рассмотрен современный нормативный поход к определению потерь в изоляции силовых высоковольтных кабелей. В стационарном режиме нагрузки (100\% -ный коэффициент нагрузки) в соответствии с действующим международным стандартом (ІЕС 60287-1-1) диэлектрические потери зависят только от напряэения и от использованного изоляционного материала. Силовые высоковольтные кабели с изоляцией из сиитого полиэтилена (СПЭ-кабели) имеют безусловные преимущества перед традициоными, что обусловило их иирокое использование во всех развитых странах и заметное сокращение использования других типов кабелей. Ряд существенных особенностей СПЭ-кабелей, которые влияют на температуру в элементах конструкции кабеля и, соответственно, на потери в них как в рабочих, так и в аварийных режимах эксплуатации, а именно: 1) большие, чем у традиционных маслом наполненных кабелей, значения площцади сечения жил и толщины изоляции; 2) больщая, чем у традиционных маслом наполненных кабелей, допустимая температура изоляции (90 $\left.{ }^{\circ} \mathrm{C}\right)$; 3) большие, чем у традицинных маслом наполненных кабелей, значения толщины полупроводящих экранов по эниле и по изоляции; 4) существенная зависимость теплопроводности и теплоемкости полиэтиленовой изоляции от температуры;5) наличие элементов конструкции с высоким удельным тепловым сопротивлением (до $\left.50{ }^{\circ} \mathrm{C} \cdot \mathrm{M} / \mathrm{Bm}\right)$, что существенно влияет на температуру в элементах конструкции СПЭкабеля и, соответственно, на потери в них. Представлены данные о потерях в системе, состоящей из изоляции и полупроводящих экранов по жиле и по изоляции СПЭ-кабеля на напряжение 110 кВ для электрофизических и конструктивных характеристик материалов системы изоляции конкретного кабеля на основе схемы замещения. Ток 6 этой изоляционной системе является комплексной величиной, и значение тангенса угла ее диэлектрических потерь при промышленной частоте определено как отношение действительного тока к реактивному. В работе выполнен расчет потерь в системе изоляции, состоящей из изоляции из сиитого полиэтилена, экрана по жсиле и экрана по изоляции из полупроводящего полиэтилена. Работа нацелена на разработку метода оценки пропускной способности СПЭ-кабелей в конкретных условиях испытаний и эксплуатации. Библ. 7, рис. 2.

Ключевые слова: силовой кабель, СПЭ-кабель, потери в изоляции, система изоляции, тангенс угла диэлектрических потерь.

Problem definition. High-voltage XLPE-cables have a number of essential peculiarities influencing the temperature mode in working as well as in emergency operation mode:

- more than for traditional oil-filled cables, values of wires sectional area and thickness of the insulation causing significant dependence of the cable heating process on wires and insulation heat capacity and losses in it;

- more than for traditional oil-filled cables, insulation permissible temperature $\left(90{ }^{\circ} \mathrm{C}\right)$ that firstly, causes high values of allowable current [1]; secondly, increases losses in structural parts of the cable that requires a separate consideration of losses in insulation [2];

- substantial dependence of thermal conductivity and heat capacity of polyethylene insulation on temperature (e.g., specific heat capacity of polyethylene at temperature of $20^{\circ} \mathrm{C}$ is $2300 \mathrm{~J} / \mathrm{kg} \cdot{ }^{\circ} \mathrm{C}$ and at $80{ }^{\circ} \mathrm{C}-3750 \mathrm{~J} / \mathrm{kg} \cdot{ }^{\circ} \mathrm{C}$ ) and the presence of elements of design with high specific thermal resistance (till $50{ }^{\circ} \mathrm{C} \cdot \mathrm{m} / \mathrm{W}$ ) which changes the

(C) L.A. Shchebeniuk, T.Yu. Antonets 
thermal conditions of insulation compared to the operation mode of the traditional oil-filled cables.

Therefore, investigation of losses in insulation of high-voltage cables with cross-linked polyethylene insulation is necessary for decision-making regarding their technical capacity and overload capacity.

Analysis of literature sources. The combination of high working intensity of the electric field (up to 8 $\mathrm{kV} / \mathrm{mm}$ or more) with long-term high insulation temperature (up to $90{ }^{\circ} \mathrm{C}$ or more) lead to the use of long-term and expensive tests [3] at which XLPE-cables are exposed hundreds of heating cycles (every of 8 hours) with simultaneous action of high voltage $1.7 \mathrm{U}$; during the cycles of heating all the major parameters are checked:

- electrical (dielectric loss tangent, the level of partial discharges);

- thermal (temperature in cable design elements and on its surface).

At the same time, the capacity of power cables is determined solely by calculation in nominal terms, i.e. at steady load (100\% load factor matched) [4]. Accordingly, the rated current $I_{n}$ is infinitely long-term at which the maximum wire temperature is set at nominal conditions environment. Practically applied computational models to determine $I_{n}$ must include the calculation of losses in the insulation of high-voltage cables [4].

Since the losses in the elements of the design of cable indirectly affect the losses in insulation but in operation the cable is almost never works in a steady maximum allowable mode, to verify specific cables use or special laboratory $[5,6]$ cable or take the manufacturer's warranty. This means the need to investigate the manufacturer specific losses in insulation cables. Obviously, standardized calculations are necessary. But for innovative products, which differs significantly from the traditional use only standardized methods are inadequate. For example, in [7] the method we use universal and unified computational models of processes of heat and mass transfer in high-voltage cables with plastic isolation to study their capacity through interval parameter estimation models. It is shown that for calculating high-capacity power cable with plastic insulation necessary joint resolution models that describe structural, electrical, thermal and economic parameters of the cable. A solution for a single-cable with cross-section of $625 \mathrm{~mm}^{2}$ for voltage of $220 \mathrm{kV}$ is presented. It was established that the optimal range of insulation thickness from $9.5 \mathrm{~mm}$ to $10.5 \mathrm{~mm}$ and further reducing the thickness of the insulation capacity of the cable is reduced.

The goal of the work is to estimate the losses power in the system of insulation of the XLPE cable for the voltage of $110 \mathrm{kV}$ at the nominal load mode using equivalent circuits.

Results of investigations. In the basis of calculation of losses in insulation of high-voltage XLPE-cable an analogy of processes of heat and mass transfer, including charges transfer processes and heat transfer process is laid. Appropriate models are identical in structure, they include both basic potential difference (electrical or thermal), flow, resistance, conductivity. Accordingly, all other elements of models describing a particular process are derived from these values, and mathematical description of a process in a system of differential equations is fairly universal and unified $[2,3]$.

In cylindrical coordinates $(r, \theta, z)$ the most suitable to describe the processes of heat transfer in cables for potential we use Poisson equation which, if the potential $\varphi$ depends only on the radius $r$ (radial field in a homogeneous substance), a potential gradient is inversely proportional to radius:

$$
-d \varphi / d r=\varphi_{0} /\left[r \cdot \ln \left(r_{2} / r_{1}\right)\right]
$$

where $r_{1}, r_{2}$ are the radii of equipotential lines between which there is a radial field in a homogeneous substance, $r_{1}<r_{2} ; \varphi=\varphi_{0}$ at $r=r_{1}$, and $\varphi=0$ at $r=r_{2}$.

This model is the main calculation model used in cable technology for the describing stationary processes of charges or heat transfer through a homogeneous substance in a radial field.

Since the potential depends on the radius only if infinitely long cable and a substance which is the process of transferring, in one way or another is heterogeneous, the application model (1) causes the error, the smaller the aforementioned conditions closer to reality. To avoid significant error we need to perform calculations for intervals of possible values of parameters and compare calculation results with the results arising from real experience.

For example, when calculating the dielectric losses in cables with polyethylene insulation we should use interval values of specific thermal insulation resistance, since this parameter depends on temperature [7]. Using a similar process of charge transfer and heat transfer to determine the distribution of the field strength in the elements of structure of the XLPE-cable if the transfer process is stationary (process parameters are independent of time) and linear, relation corresponding motion potential difference (for example, the temperature difference $\tau, \mathrm{K}$ ) to intensity of flow (for heat flow $P, \mathrm{~J} / \mathrm{s}$ ) is constant. Then for flow through any uniform cable design element:

$$
\tau=P \cdot S
$$

where $S$ is the resistance of the cable design element. 
If the flow of heat and radial, the thermal insulation resistance per unit length of the cable is determined by formula:

$$
S_{i}=\sigma_{i} \ln \left(r_{2} / r_{1}\right) / 2 \pi
$$

where $r_{1}, r_{2}$ ate the radii of equipotential lines of the radial field for wire and insulation, respectively; $\sigma_{i}$ is the specific thermal resistance of insulation.

The system of the XLPE-cable insulation consists of successive layers of different materials: a semiconductor screen for wire, insulation and a semiconductor screen for insulation. So, to calculate the charge transfer process at $\mathrm{DC}$ in such a system we should take into account different values of resistivity of all three elements.

Semiconductor screens for wire and for insulation consist of composite material - XLPE filled with acetylene soot. This material structure and characteristics can be seen as imperfect dielectric, conducting electric current. For approximate estimation of power energy dissipation in semiconductor structures of specific cable structures' screens we can use different equivalent circuits of the system «semiconductor screen for wire - insulation semiconductor screen for insulation», for example, a known parallel equivalent circuit for each element of the system shown in Fig. 1.

If equivalent circuit parameters $C_{1}, C_{2}, C_{3}$ and $R_{1}$, $R_{2}, R_{3}$ are determined by known formulae for the radial electric field:

$$
C=2 \pi \cdot \varepsilon \cdot \varepsilon_{0} / \ln \left(r_{2} / r_{1}\right),
$$

where $\varepsilon_{0}$ is the electric constant, $\varepsilon$ is the relative dielectric constant of insulation; $\varepsilon_{0}=1 / \mu_{0} c_{0}^{2}=8.85 \cdot 10^{-12} \mathrm{~F} / \mathrm{m}$; $c_{0}=2.99 \ldots \times 10^{8} \mathrm{~m} / \mathrm{s}$ is the speed of light in vacuum; $\mu_{0}=4 \pi \cdot 10^{-7} \mathrm{H} / \mathrm{m}$ is the magnetic constant;

$$
R=(2 \pi \cdot \gamma)^{-1} \cdot \ln \left(r_{2} / r_{1}\right)
$$

where $\gamma$ is the electrical conductivity of the element's material, then corresponding complex impedances of these elements are determined by the common formula (6).

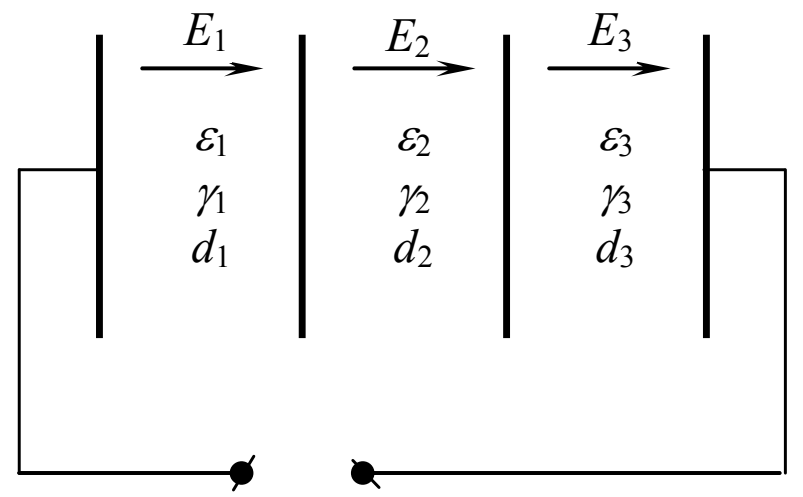

Fig. 1. A circuit of the system «semiconductor screen for wireinsulation - semiconductor screen for insulation»: $\varepsilon_{1}, \varepsilon_{2}, \varepsilon_{3}-$ relative dielectric constants of the elements' material; $\gamma_{1}, \gamma_{2}, \gamma_{3}$ - electrical conductivities of the elements' material; $d_{1}, d_{2}, d_{3}-$ thicknesses of the system's elements
Complex impedances of the insulation system's elements:

$$
Z=-j X_{c} \cdot R /\left(R-j X_{c}\right)
$$

where $R, X_{c}$ are the active and reactive resistances of the corresponding system's element, $X_{c}=(\omega C)^{-1}=(2 \pi f \cdot C)^{-1}$; $f$ is the frequency; $C$ is the capacitance o the insulation system's element.

Current that flows through the insulation and the cable semiconductor screens is defined phase cable voltage $U$ and the sum of complex impedances of cable insulation system's elements:

$$
I=U /\left(Z_{1}+Z_{2}+Z_{3}\right) \text {. }
$$

Voltage on the system's elements and active losses on it are determined by formulae:

$$
\begin{array}{ll}
U_{1}=I \cdot Z_{1} ; & P_{1}=U_{1} \cdot[\operatorname{Re}(I)-j \operatorname{Im}(I)] ; \\
U_{2}=I \cdot Z_{2} ; & P_{2}=U_{2} \cdot[\operatorname{Re}(I)-j \operatorname{Im}(I)] ; \\
U_{3}=I \cdot Z_{3} ; & P_{3}=U_{3} \cdot[\operatorname{Re}(I)-j \operatorname{Im}(I)] .
\end{array}
$$

Losses in the insulation system are determined by formula:

$$
P=U \cdot[\operatorname{Re}(I)-j \operatorname{Im}(I)] .
$$

Thus, the losses in the insulation system $P$ depend on the voltage associated with the electrical characteristics of the used material (relative dielectric constant $\varepsilon$, specific conductivity $\gamma$ ) and the geometric dimensions of the insulation system's elements.

On the other hand, practically applicable and recommended by the corresponding International Standard [2] the formula by which we determine $P_{d}$ losses in dielectric of power high-voltage cables, is the ratio, including the value of the dielectric losses tangent $\operatorname{tg} \delta$ :

$$
P_{d}=\omega C U^{2} \operatorname{tg} \delta,
$$

where $\omega$ is the angular frequency, $\omega=2 \pi f ; C$ is the capacitance per unit length; $U$ is the phase voltage.

Values of the dielectric losses tangent are determined experimentally. For high-voltage XLPE cables in [2] the value $\operatorname{tg} \delta=0.0015$ is indicated. Losses power $P_{d}$ in the dielectric of the cable АПвЕВнгд $1 \times 500$ of $110 \mathrm{kV}$ by (12) is $P_{d}=0.33 \mathrm{~W} / \mathrm{m}$.

The value of power losses in the insulation system calculated by (11) for this cable is $P=0.34 \mathrm{~W} / \mathrm{m}$ with at dielectric conductivity of $10^{-11} \mathrm{~S} / \mathrm{m}$ and conductivity of semiconductor screens material ranging from $10^{-1} \mathrm{~S} / \mathrm{m}$ to $10^{1} \mathrm{~S} / \mathrm{m}$. Obviously, the use of more complex circuits of the system «semiconductor screen for wire - insulation semiconductor screen for insulation» can provide more accurate calculations. But compliance of $P_{d}$ and $P$ values are sufficient to address through this equivalent circuit of the problem, namely - a rough estimate of losses in semiconductor high-voltage cable screens compared to losses in its insulation. 
Using (7) the dissipation factor of the insulation system can be defined as the ratio of real current to reactive:

$$
\operatorname{tg} \delta=\operatorname{Re}(I) / \operatorname{Im}(I) .
$$

Fig. 2 shows an illustration of the results of calculations by (13) in the form of dependence of dissipation factor of the insulation system of the XLPE cable for voltage of $110 \mathrm{kV}$ on the conductivity of the material of the screen. These data, first, indicate that the reduction of the electrical conductivity of the material of the screen causes increase of losses in the screen, but in a fairly wide range of values of conductivity of the material of the screen which includes real values in the appropriate cable constructions, namely from $10^{-3} \mathrm{~S} / \mathrm{m}$ to $10^{2} \mathrm{~S} / \mathrm{m}$, power losses in the semiconductor screens are negligible compared to the power losses in insulation.

Second, maximum on the dependence of the dissipation factor of the insulation system of the XLPE cable for the voltage of $110 \mathrm{kV}$ on the screen material conductivity $\gamma_{e}$ for any value of relative dielectric constant of the material of the screen is far from the real values $\gamma_{e}$ (at least five orders) therefore this maximum has no practical value.

Third, at real values of relative dielectric constant of the material of semiconductor screens of high-voltage XLPE cables insulation (at least 100 at frequency of 50 $\mathrm{Hz})$ the maximum $\operatorname{tg} \delta$ approaching to normative $(\operatorname{tg} \delta=0.0015)$. This demonstrates the acceptability of the equivalent circuit as a serial connection of complex impedances of three elements of the insulation system. All elements are represented as a parallel connection of active and reactive resistance.

Maximum on the dependence of the dissipation factor of the XLPE cable insulation system takes place under condition of equality of the absolute values of active and reactive resistance of semiconductor screens:

$$
\begin{aligned}
& \operatorname{Re}\left(Z_{1}\right)=-\operatorname{Im}\left(Z_{1}\right) ; \\
& \operatorname{Re}\left(Z_{3}\right)=-\operatorname{Im}\left(Z_{3}\right),
\end{aligned}
$$

which reflects the mainly capacitive nature of current through the semiconductor screen at real values of electrophysical characteristics of semiconductor material of the screen.

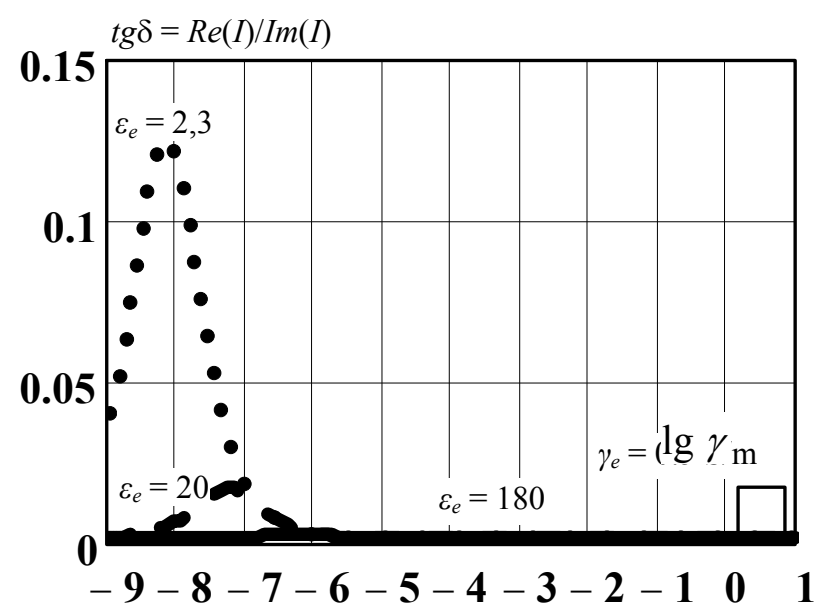

Fig. 2. Dependencies of the dissipation factor of the XLPE cable insulation system for voltage of $110 \mathrm{kV}$ on the conductivity of the material of the screen at different relative permittivity of the material of the screen $\varepsilon_{e}$ (results obtained for cable with insulation thickness of $16 \mathrm{~mm}$ are shown)

\section{Conclusions.}

1. Using an equivalent circuit analysis the power losses in the XLPE cable insulation system for the voltage of $110 \mathrm{kV}$ at the nominal load mode is determined.

2 . Based on the fact that the value $\operatorname{tg} \delta$ XLPE by Standards IEC is 0.0015 it is determined that the power losses in the insulation system of the cable АПвЕВнгд $1 \times 500$ for $110 \mathrm{kV}$ is $0.33 \mathrm{~W} / \mathrm{m}$. The value of the power losses in the insulation system calculated by the equivalent circuit for the same cable is $0.34 \mathrm{~W} / \mathrm{m}$ at dielectric conductivity of $10^{-11} \mathrm{~S} / \mathrm{m}$ and conductivity of semiconductor screens material ranging from $10^{-1} \mathrm{~S} / \mathrm{m}$ to $10^{1} \mathrm{~S} / \mathrm{m}$.

3. Current flowing through the insulation and the cable semiconductor screens is determined by phase voltage and the sum of complex impedances of these structural elements of the cable. The criterion of correctness of calculations by the equivalent circuit is beneficial coincidence of these results with international regulations data. Therefore, it can be concluded that calculations by the adopted equivalent circuit can be used to approximate estimates of the need to take into account losses in semiconductor screens of the high-voltage cable compared to losses in its insulation.

4. In the sufficiently wide range of values of conductivity of the material of the screen which includes real values in the appropriate cable designs, in particular from $10^{-3} \mathrm{~S} / \mathrm{m}$ to $10^{2} \mathrm{~S} / \mathrm{m}$, power losses in the semiconductor screens are negligible compared to the power losses in insulation.

5. Reduce of the conductivity of the material of the screen causes the increase of losses in the cable insulation system. Accordingly, on the dependence of the dissipation factor of the insulation system of the high-voltage XLPE 
cable the maximum is observed. The value of the electrical conductivity of the material of the screen $\gamma_{e}$ at which the maximum of losses:

- is far from the real values $\gamma_{e}$ (at least five orders) that has no practical value;

- at the real values of the relative permittivity of the semiconductor screens material in the insulation system of high-voltage XLPE cables (at least 100), the maximum $\operatorname{tg} \delta$ approaches to the regulatory value $(\operatorname{tg} \delta=0.0015)$;

- maximum on the dependence of the dissipation factor of the insulation system of the XLPE cable takes place under condition of equality of the absolute values of active and reactive resistances of semiconductor screens that are property of the adopted equivalent circuit.

\section{REFERENCES}

1. Karpushenko V.P., Shchebeniuk L.A., Antonets Yu.O., Naumenko O.A. Sylovi kabeli nyz'koyi ta seredn'oyi napruhy. Konstruyuvannya, tekhnolohiya, yakist' [Power cables of low and medium voltage. Designing, technology, quality]. Kharkiv, Region-inform Publ., 2000. 376 p. (Ukr).

2. IEC 60287-1-1: 2001. Electric cables. Calculation of the current rating. Part 1-1: Current rating equations (100\% load factor) and calculation of losses - General. $-65 \mathrm{p}$.

3. SIGRE № 303 «Revision of qualification procedures for high voltage and extra high voltage AC extruded underground cable systems», 2006.

How to cite this article:

Shchebeniuk L.A., Antonets T.Yu. Investigation of losses in insulation of high-voltage cables with XLPE insulation. Electrical engineering \& electromechanics, 2016, no.4, pp. 58-62. doi: 10.20998/2074-272X.2016.4.08.
4. IEC 60287-2-1: 2001. Electric cables. Calculation of the current rating. Part 2-1: Thermal resistance - Calculation of thermal resistance. $-84 \mathrm{p}$.

5. IEC 62067: Ed. 1.1b: 2006. Power cables with extruded insulation and their accessories for rated voltages above $150 \mathrm{kV}$ $\left(U_{\mathrm{m}}=170 \mathrm{kV}\right)$ up to $500 \mathrm{kV}\left(U_{\mathrm{m}}=550 \mathrm{kV}\right)-$ Test methods and requirements. $-90 \mathrm{p}$.

6. HD 632 S1: 1998. Power cables with extruded insulation and their accessories for rated voltages above $36 \mathrm{kV}\left(U_{\mathrm{m}}=\right.$ $42 \mathrm{kV})$ up to $150 \mathrm{kV}\left(U_{\mathrm{m}}=170 \mathrm{kV}\right)$ Part 2: Additional test methods.

7. Shchebeniuk L.A., Antonets T.Yu. To determine the capacity of high-voltage power cables with plastic insulation. Visnyk NTU «KhPI» - Bulletin of NTU «KhPI», 2011, no.3, pp. 152-157. (Ukr).

Received 05.05.2016
L.A. Shchebeniuk ${ }^{1}$, Candidate of Technical Science, Professor, T.Yu. Antonets ${ }^{1}$, Postgraduate Student,
${ }^{1}$ National Technical University «Kharkiv Polytechnic Institute», 21, Kyrpychova Str., Kharkiv, 61002, Ukraine.
e-mail: agurin@kpi.kharkov.ua 